\title{
influencia del yeso sobre la velocidad de hidratación del cemento portland
}

\author{
einfluss des gipses auf die hydratationsgeschwindigkeit von portlandzement \\ G. YAMAGUCHI $y$ otros
}

(๕Zement-Kalk-Gips», 13, núm. 10, octubre 1960, pag. 467.)

Para esclarecer la influencia del yeso sobre el fraguado y endurecimiendo del cemento, los autores estudiaron el grado de hidratación de los cuatro principales minerales del clínker de cemento Portland y el efecto del yeso sobre ellas. Haciendo uso del análisis cuantitativo de rayos $\mathrm{X}$, se determinó la porción no hidratada. Simultáneamente, se determinaron los tiempos de fraguado y las resistencias. Los ensayos se llevaron a cabo sobre tres clínkeres sintéticos de diferentes composiciones y sobre dos clínkeres de cemento Portland comerciales.

El grado de hidratación del aluminato tricálcico es el más elevado en comparación con los otros minerales del clínker. Los clínkeres con elevado contenido de aluminato tricálcico y bajo contenido de alita muestran sin yeso un fraguado rápido y con yeso un fraguado normal.

El grado de hidratación de la celita es bastante regular inmediatamente después del amasado: Es del 8 al $20 \%$ y no se rebaja por la adición de yeso más que algunas unidades por ciento. Los clínkeres cuyo contenido en celita es elevado y el del aluminato tricálcico bajo, no muestran una rigidez importante sin yeso. $\mathrm{El}$ efecto retardador del yeso es provocado por la reducción de la velocidad de hidratación del aluminato tricálcico activo.

Para determinar la relación entre el grado de hidratación y el desarrollo de la resistencia del cemento Portland, se han hallado las resistencias de los primas $1 \times 1 \times 7 \mathrm{~cm}$ (relación cemento/arena $=1,3$; factor agua/cemento, 0,50 ). El grado de hidratación se ha determinado por análisis cuantitativo de rayos $\mathrm{X}$ en pastas con el mismo factor agua/cemento.

La alita muestra el grado de hidratación más elevado; el del aluminato tricálcico era un poco más bajo. La velocidad de hidratación de la alita se acelera por adición del yeso. El grado de hidratación de la belita y de la celita era más elevado con yeso que sin adición. El yeso retardó al aluminato tricálcico.

Las resistencias de los prismas de mortero muestran un máximo con adición de $2,5 \%$ de $\mathrm{SO}_{3}$ en forma de yeso, a excepción de los clínkeres con bajo contenido en alita y alto en aluminato tricálcico. 